\title{
PINNACLE SYNGENETIC KARST IN NAMBUNG NATIONAL PARK, WESTERN AUSTRALIA
}

\author{
STOLPIČASTI SINGENETSKI KRAS V NARODNEM PARKU \\ NAMBUNG V ZAHODNI AVSTRALIJI
}

Matej LIPAR ${ }^{1}$

\begin{abstract}
UDC 911.2:551.44(941)

Matej Lipar: Pinnacle syngenetic karst in Nambung National Park, Western Australia

Simultaneous karstification and lithification of aeolian calcarenite in the southwest coastal part of Western Australia produced syngenetic karstic geomorphological features, such as solution pipes, maze caves, collapsed dolines and pinnacles. The formation of these geomorphological features was greatly influenced by the poor cementation and matrix porosity of the calcarenite.

Pinnacles, calcarenite pillars up to 5 metres tall with one or more peaks and various types of sediment layers, are most numerous and densest in an area called The Pinnacles in Nambung National Park, Western Australia. Their detailed characteristics and origin are still partially unknown and controversial. Theories suggest that the pinnacles are the final product of one or more of corrosive expansion and coalescence of solution pipes, cemented sediment surrounding the roots, cemented fill of solution pipes, products of focused cementation or remainders of tree-trunks. This article presents descriptions of pinnacles in Nambung National Park based on my fieldwork and suggests a polygenetic origin for the pinnacles, with roots playing a major role. The genesis of pinnacles is far more complex than the theories presented so far.
\end{abstract}

Key words: pinnacles, syngenetic karst, calcarenite, Nambung National Park, Western Australia.
Izvleček

UDK 911.2:551.44(941)

Matej Lipar: Stolpičasti singenetski kras $v$ narodnem parku Nambung $v$ Zahodni Avstraliji

Na jugozahodnem obalnem delu Zahodne Avstralije so se zaradi sočasne litifikacije in zakrasevanja eolskega kalkarenita razvile singenetske kraške geommorfološke oblike, kot so korozijske cevi, labirintne jame, udornice in stolpiči. Na razvoj omenjenih kraških geomorfoloških oblik sta vplivali predvsem šibka cementacija in medzrnska poroznost kalkarenita. Stolpiči, ki predstavljajo do 5 metrov visoke kalkarenitne stebre $\mathrm{z}$ enim ali več vrhov in različnimi sedimentnimi plastmi, se najbolj na gosto in v največjem številu pojavljajo v narodnem parku Nambung, v območju z imenom The Pinnacles. Dosedanji opisi njihovih značilnosti in nastanka so še vedno delno nejasni oziroma neenotni. Po teorijah naj bi bili stolpiči končni produkt korozijskega širjenja korozijskih cevi, cementiran sediment okoli korenin, cementirano polnilo korozijskih cevi, produkt točkovne cementacije, ali pa ostanki drevesnih debel. Na podlagi terenskega dela sta v članku predstavljena opis stolpičev v narodnem parku Nambung in njihova geneza kot rezultat večih dejavnikov s poudarjeno vlogo korenin. Kompleksnost njihove geneze je večja kot jo sicer predstavljajo dosedanje teorije.

Ključne besede: stolpiči, singenetski kras, kalkarenit, narodni park Nambung, Zahodna Avstralija.

\section{INTRODUCTION}

\section{THE PINNACLES AREA}

The Pinnacles area is part of Nambung National Park, situated in the southwestern coastal part of Western Australia, about 240 kilometres north of Perth. The nearest settlements are the towns of Cervantes and Jurien Bay north of the national park (Fig. 1).

Management of the region is aimed mainly at protecting the flora and fauna, underground water, karstic 


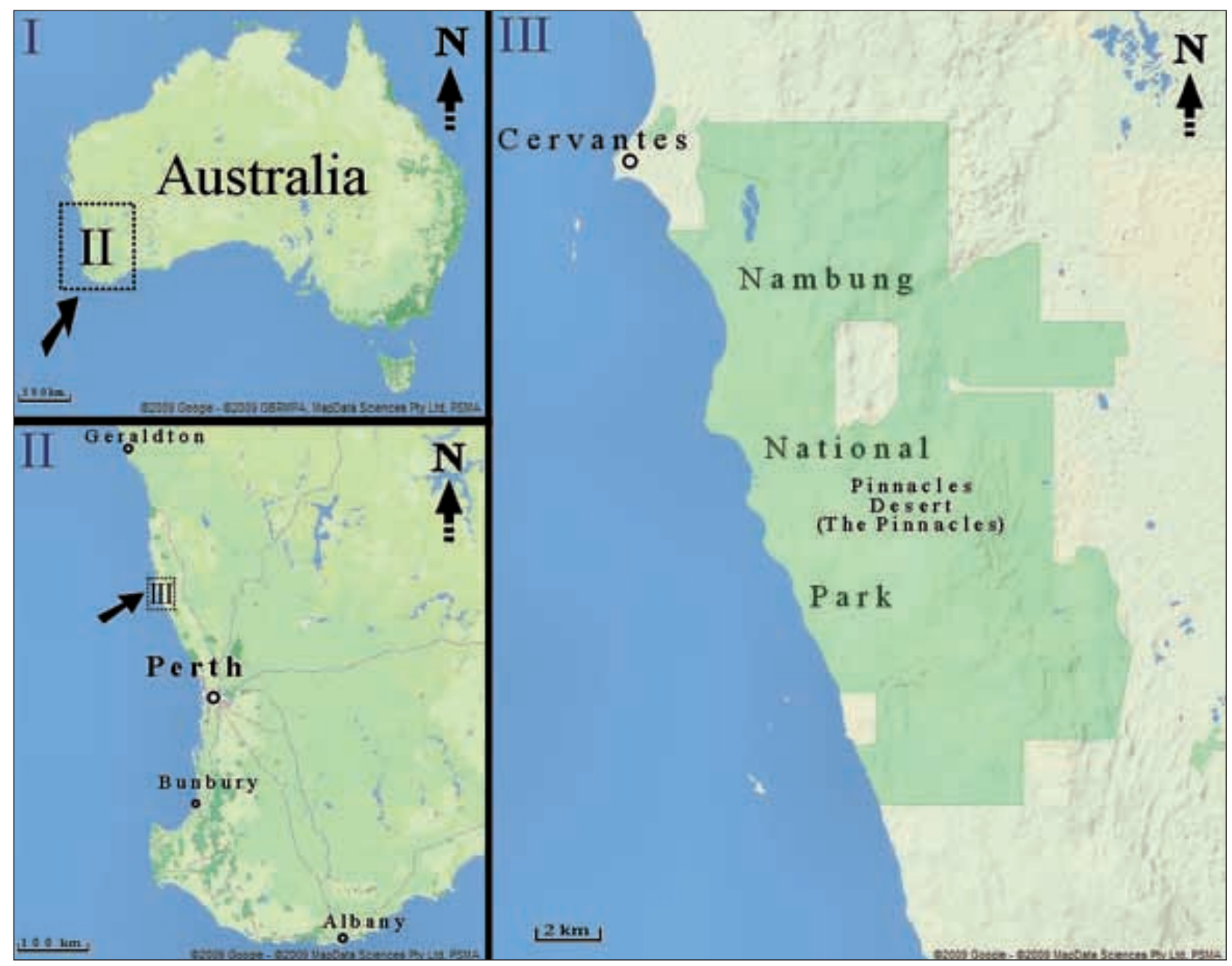

Fig. 1: A location map of Nambung National Park (author: M. Lipar; background terrain map: Google Imagery / Map data).

features (caves, pinnacles) and archaeological sites (Nambung ... 1998).

The Pinnacles area has a Mediterranean climate with hot and dry summers and mild rainy winters. Most rainy days are between May and September, and the average annual rainfall for Cervantes between 1990 and 2007 is $509 \mathrm{~mm}$ (Annual ... 2007). Average maximum temperatures for Jurien Bay (a settlement $21 \mathrm{~km}$ north of Cervantes) between 1969 and 2008 are $24.7^{\circ} \mathrm{C}$, and average minimum temperatures are $13^{\circ} \mathrm{C}$ (Climate ... 2008).

The Pinnacles area is geologically mapped at scales of 1:250 000 (Lowry et al. 1973) and 1:100 000 (Mory 1995). Based on the geological maps, the area is covered with Quaternary sediments that increase in age in a landward (eastern) direction. The eastern and oldest sediment is the Bassendean Dune System, deposited in the middle Pleistocene. The Spearwood Dune System occurs next, closer to the coast. It was deposited from the middle to late Pleistocene. The youngest, the Quindalup
Dune System, deposited in the Holocene, lies closest to the coast.

Cemented dunes in The Pinnacles area are composed of aeolian calcarenite, known as the Tamala Limestone, previously called the Coastal limestone. The term Tamala Limestone was applied to the Zuytdorp Cliffs calcarenite. From there, the name spread to the entire calcarenite complex in the southwest coastal region of Western Australia. Because the Tamala Limestone includes calcarenites of different ages, which makes the term very general, Hearty and O'Leary (2008) suggested a revision of the nomenclature, but their suggestions are not yet officially accepted.

The main characteristics of aeolian calcarenites are high matrix porosity, weak cementation and coarse to medium sized sand grains. Lithification in aeolian calcarenites differs from that in other limestones as it took place at or near the surface, rather than during deep burial. The extensive accumulation of carbonate dunes 
resulted from a high productivity of carbonate-skeleton organisms in the sea due to the warm Leeuwin current coupled with aridity and constant strong wind, blowing towards the inland. Carbonate sand grains in the calcarenite are mostly the remains of aragonite foraminifera, molluscs, red algae and echinoderms (Hearty \& O'Leary 2008). Skeletal grains comprise from $30 \%$ to more than $80 \%$ of the sand and, with an average between $60 \%$ and $70 \%$. Non-carbonates components are quartz and orthoclase (Csaky 2003; McNamara 1995; Mory 1995).

\section{SYNGENETIC KARST}

Term "syngenetic karst" (Greek sýn - together, at the same time; Greek génesis - development, genesis, beginning), was introduced by Jennings (1968) and refers to karst landscapes and features that form simultaneously with the lithification of a sediment. The lithification and karstification occur at the same time (Jennings 1968; Grimes 2002, 2006).

Syngenetic karst is usually formed on soft carbonate rocks such as aeolian and marine calcarenite (Grimes 2006) but may also occur on gypsum and halite (Sando 1987). The description of syngenetic karst here is based on the Australian aeolian calcarenites.

In aeolian calcarenites lithification is by the simultaneous solution of carbonate grains and its reprecipitation elsewhere in the dune sand. During lithification matrix porosity stays relatively the same; only an upper layer of cemented calcarenite - calcrete - becomes less porous, harder and erosion resistant. In places cemented layers also occur at greater depth as a result of burial of the calcrete by younger dune sediment or from cementation at a saturated groundwater level (Grimes 2006).

In the early stage of syngenetic karst, cementation begins around plant roots, to form rhizoliths and just below the surface in the calcrete band. Solution pipes also appear in this early stage. However, caves are mostly not yet developed because the calcarenite is not cemented enough - an exception is the formation of small caves beneath the calcrete layer. Where solution occurs at depth, at the groundwater level, the dune sand subsides to fill any incipient cavities (Grimes 2006).

The late stage of syngenetic karst begins when the calcarenite becomes cemented strongly enough for caves to form in it. Other karst features also begin to form and are influenced by the matrix porosity of the calcarenite, slow underground water flow and the absence of joint porosity. Among the newly formed karst features are syngenetic maze caves with low and wide connected tunnels. Karrens occur rarely due to the absence of hard rock and joint porosity (Grimes 2006).

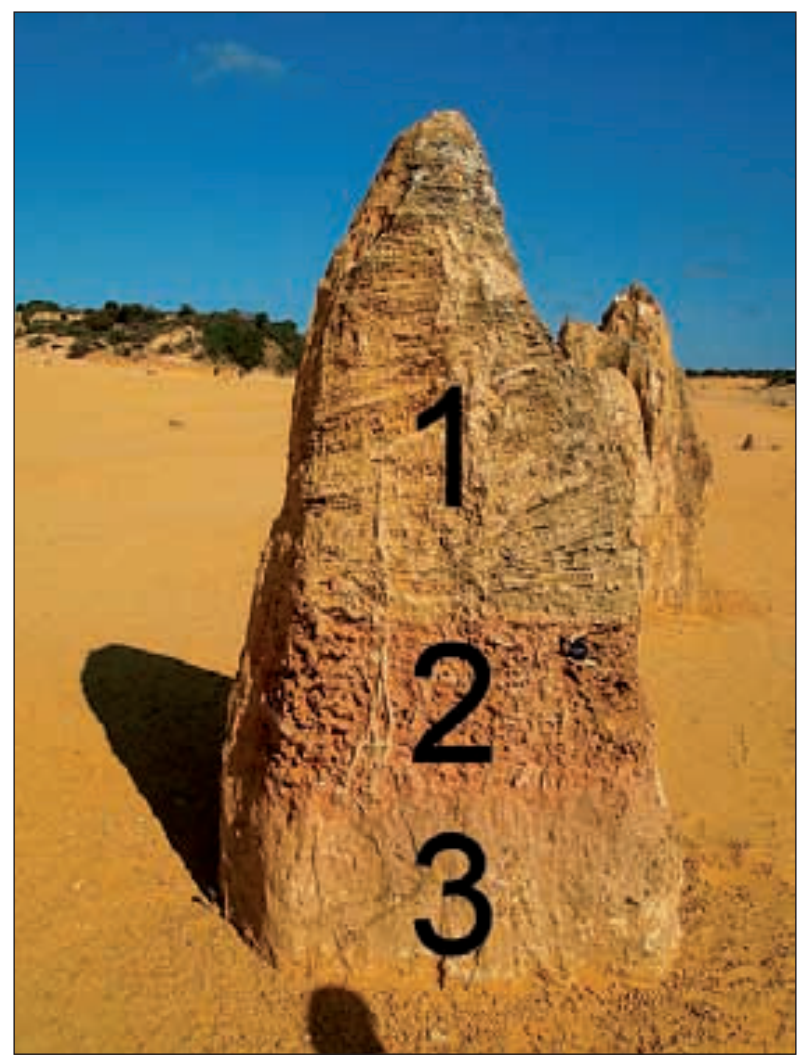

Fig. 2: A pinnacle ( 2 metres high) with three different layers; dune bedding (1), paleosoil (2) and calcrete (3) (Photo: M. Lipar).

Syngenetic karst in Australia is formed in the southwestern coast of Western Australia, the Eyre Peninsula and Kangaroo Island in South Australia and in coastal areas between South Australia and Victoria. To a lesser extent it also occurs on the Nullarbor Plain, on islands in Bass Strait, Lord Howe Island, Great Barrier Reef islands and Gulf of Carpentaria islands (Grimes 2006).

In this paper the detailed characteristics of the pinnacles in Nambung National Park will be presented. Their genesis will also be discussed, regarding theories presented by Lowry (1973), McNamara (1995), Grimes (in prep.) and Hearty and O'Leary (2008) and the characteristics of pinnacles collected during field work.

\section{FIELD WORK METHODS}

This research was based on field-work and the analysis of rock samples.

Field work included a morphological and morphometric examination of karst forms (especially the pinnacles) in The Pinnacles area; photographing and documenting the landscape, forms and other important aspects of the area; and collecting rock samples, which were later analyzed. 
The mineral composition of samples was determined by X-ray powder difraction at the Department of Geology, Faculty of Natural Sciences and Engineering, University of Ljubljana.

The management of The Pinnacles area restricted the collection of samples, excavation and other field methods that could damage the landscape or its features. Management policy also constrains the publication of detailed geomorphological maps that should not, for example, include the exact locations of caves. All fieldwork for this paper was performed according to the regulations for Nambung National Park.

\section{THE PINNACLES}

The pinnacles are calcarenite towers (Fig. 8), formed about 4 to 6 kilometres inland from the sea at several locations between Perth and Cervantes and are most abundant in the Nambung National Park.

They have various shapes - some are conical, some have mushroom-like shape, others are cylindrical with a rounded top, some are hollow and some have multiple peaks. Often they are partially buried with quartz (Hearty \& O'Leary 2008) dune sand. Due to ongoing erosion, transport and accumulation of sand, some pinnacles become covered while others are exhumed (McNamara 1995). The accumulation and erosion of the surrounding sand influence the relative height of the pinnacles, which varies from barely noticeable to 5 metres. The connections are seen between bases of certain adjoining pinnacles. The average width of the pinnacles ranges from 0.2 to 2 metres.

Spacing between the pinnacles varies enormously, from few centimetres to more than 20 metres. Despite their random occurrence, pinnacles usually occur in dense fields with an average spacing between 0.5 and 5 metres. When comparing pinnacles (height, width, shapes and material) from different dense fields in The Pinnacles area, the distinction is much greater than comparing only neighbouring pinnacles in a single dense field.
The pinnacle material shows great variety. Some material is an erosional remainder of primary calcarenite and its component layers, such as bedded dune sand, calcrete and paleosoil (Fig. 2). Other pinnacle material is secondarily cemented pipe/tube fill (Fig. 5). Certain pinnacles contain both sorts of material together (Fig. 6). Dark red flat and round laterite pebbles (average $1 \mathrm{~cm} \mathrm{x}$ $1 \mathrm{~cm} \times 0.5 \mathrm{~cm}$ ) were found in the secondarily cemented pipe/tube fill (Fig. 7). They consist of minerals hematite, quartz, orthoclase feldspar, illite and dickite (X-ray identification by Dobnikar 2008). In addition, the calcarenite that represent a bedded dune sand consists of calcite, quartz and orthoclase feldspar (X-ray identification by Dobnikar 2008).

Rhizoliths, which indicate the presence of plant roots in the past, are often exposed on pinnacles. Also strongly cemented rims of solution pipes are found in pinnacle material.

Some pinnacles are covered with a layer of carbonate cement, which can be localised and very thin (some millimetres), but it can also cover a large part of a pinnacle.

The pinnacles were formed as a result of localised corrosion and cementation, followed by wind erosion of the soft or loose sand to leave the harder cemented areas as upstanding pinnacles.

\section{DISCUSSION}

THEORIES OF PINNACLE GENESIS

Lowry (1973) suggested that the pinnacles are a final product of corrosive expansion and coalescence of solution pipes. He listed three stages. To summarize, in the first stage, there is deposition of dunes, their stabilization by vegetation and later their cementation. In the second stage, formation of calcrete and solution pipes begins. In the third stage, there is an expansion of and coalescence of the solution pipes, by ongoing solution of the calcarenite and consequent formation of the pin- nacles as remnants of the cemented material. In the last stage, erosion of the uncemented or weakly cemented sand exposes the solid pinnacles. Lowry (1973) also mentioned that the upper rounded parts of the pinnacles most possibly be calcrete and that broken pinnacles do not seem to show any concentric sedimentation, which would be expected if the pinnacles were the cemented fill of solution pipes.

McNamara (1995) followed Lowry's theory and improved it with the addition that some of the pinnacles 
with diameters up to 1 metre could have formed by the cementation of sediment surrounding plant roots, and that some of the small pinnacles could be the remains of cemented fill of solution pipes. He also emphasized the importance of roots, in that they might have pierced the calcrete and initiated development of the solution pipes (McNamara 1995).

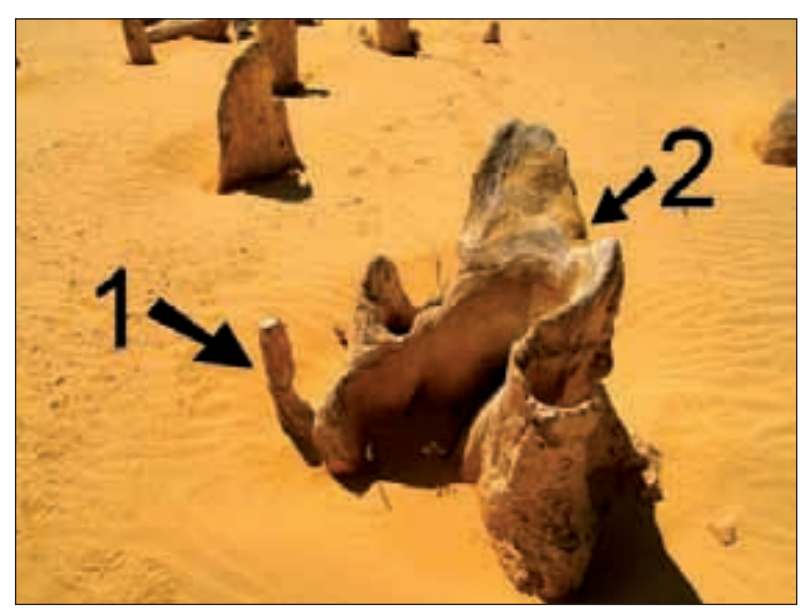

Fig. 3: A small pinnacle ( 0.5 metres high), mostly covered with quartz sand, that has a rhizolith (1) and well cemented rims of several solution pipes (2) (Photo: M. Lipar).

Grimes (in prep.) suggests a polygenetic view adding the possibility of focused cementation to the mechanisms suggested by Lowry (1973) and McNamara (1995). Focused cementation is a similar process to solution pipe formation: the difference being that the focused water flow is non-aggressive and saturated, which causes cementation instead of dissolution. The source of saturated water could be an overlying soil layer or a younger dune, which has accumulated over the primary dune. However, Grimes (in prep.) noted that the process of focused cementation would be self-inhibiting because the porosity of the material would be reduced and divert the water flow. Consequently, instead of extending downwards it would start to spread in a horizontal direction. The final product would be an evenly cemented entire layer, but in the early stages erosion of the surrounding less-cemented material would expose some strongly cemented cylinders - pinnacles.

Hearty and O'Leary (2008), who based their studies in the Bahamas, have interpreted pinnacles as the remains of tree-trunks that were buried within the dunes. They proposed that water flows became concentrated in tubes left by rotting tree trunks and the space became filled with sediment, which was then cemented to a more solid material than the surrounding rock. The erosion of the surrounding material later exposed the pinnacles (Hearty \& O'Leary 2008).

They also estimated the age of the host calcarenite by amino acid geochronology at about 400000 years. They said that "the complexity and advanced stages of diagenesis of the pinnacles, manifest by massive calcretes and complex internal structure, combined with their inland morphostratigraphic position" suggests that they are of a similar age to their host sand. However, to suggest a single age for the pinnacles might be misleading as some pinnacles could have formed in several stages and on material of several ages. This is discussed later in section Pinnacles material.

\section{THE INFLUENCE OF CORROSION}

If the rain water in the area of The Pinnacles sank evenly beneath the entire surface and its flow was not concentrated in some spots, the likelihood of formation of pinnacles (and of solution pipes, which importance will later be discussed in the section Secondarily cemented pipe fill) would be minimal. For the rainfall to sink evenly, a homogeneous matrix porosity of the rock and a lack of joints is necessary, as is a homogeneous resistance to corrosion. However, in the opposite case some parts would corrode easier and faster and that would create a channel that would further concentrate the sinking water. A uniform sinking would also imply a complete lack of vegetation, because vegetation, when present, influences the water flow concentration with its surface and underground parts (roots, stems, etc.).

The presence of solution pipes indicates that in The Pinnacles area the rainfall did not sink evenly, triggering selective, and in some places more concentrated corrosion which formed an uneven surface; low where water was concentrated and corroding and higher between those areas, where we find the present pinnacles. The pinnacles represent a significantly more resistant or locally less porous part of the surface. Some of the pinnacles are hollow or their sides expose sections of older solution pipes, this means that certain pinnacles occupy areas where sinking water flow was once locally concentrated.

In the host sediment we find rhizoliths, which implies that when lithification of the material took place, there were plants present, which would have contributed to the concentration of the water flow via their leaves, trunks, and roots.

The process of corrosive expansion, deepening and coalescence of the less resistant, more porous, parts of the rock was probably also accelerated by soil. Its existence is deduced from paleosoil horizons, preserved within some pinnacles. If soil is present, it gathers where hollows in the rock are being corrosively expanded and deepened. When sinking through a larger amount of soil, the water 
becomes more aggressive, which enhances the corrosion beneath the hollow, compared to those areas where there was less corrosion from the beginning.

\section{THE INFLUENCE OF WIND EROSION}

The aeolian calcarenite of the sand dunes, and the pinnacles, was deposited by wind. As well as pinnacles, in this area there is also a weakly cemented calcarenite, which occurs as single small dunes-relicts (up to 3 metres high and 4 metres wide) and is usually located on a higher ground level than the pinnacles, which suggests a younger age than the calcarenite of the pinnacles; there are also modern mobile dunes or just loose sand in the area. This transportation and deposition of material of different ages points to constant or at least periodical wind presence, which indicates that wind erosion may have contributed to the formation of the pinnacles.

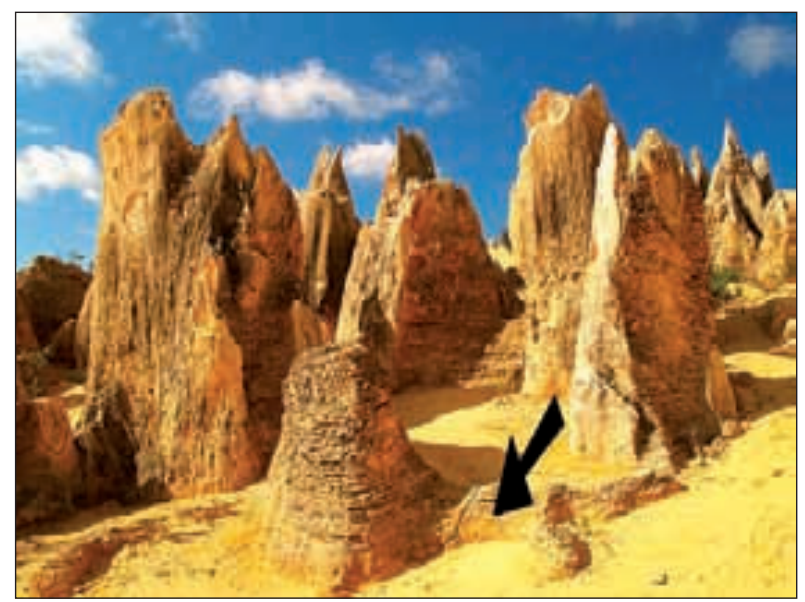

Fig. 4: Pinnacles that represent a well-bedded primary calcarenite ( $2-3$ metres high). The pointer shows the low ridges of material, that connect the pinnacles at the base (Photo: M. Lipar).

The presence of rhizoliths in the pinnacle material proves that at the time of the material lithification the surface was covered with plants. Probably there was a time when the entire vegetation disappeared due to fire, drought or burial by new dune sand. The wind erosion depends on vegetation density and that is why we can say that wind did not always influence the pinnacles formation to the same degree. It probably had an important role in eroding away less resistant material between separate pinnacles and in eroding the pinnacles themselves.

The pinnacles were completely covered at least once (McNamara 1995). The sand is still covering some and exhuming others. Wind erosion is nowadays constantly present, but despite the fact that wind erosion is strongest near ground, the mushroom-like pinnacles shapes, that are usually significant for a desert environment with strong wind erosion, have not formed. That is because the ground surface around the pinnacles has been rising and falling in response to erosion and deposition of the sand, and the wind erosion of the pinnacle sides has occurred at varying levels. However, the mushroom-like shape that some pinnacles have is, instead, a result of the stronger resistance of the upper cemented parts (the calcrete), so that the lower, softer, parts have been eroded preferentially.

\section{PINNACLES MATERIAL}

Preservation of the pinnacles means that the pinnacle material was more resistant than the surrounding material. The stronger resistance was most likely a result of greater cementation of the carbonate. A minor percentage of pinnacles are not composed of a resistant material as a whole, but only on the surface wall, and their insides are hollow spaces or composed of less resistant material that is preserved because of the protection of the resistant surface wall.

A layer of carbonate cement, that some pinnacles are covered with, makes the structure of the material behind it unrecognizable and therefore hard to determine the exact percentage of pinnacles, regarding its different material. The layer has most probably been formed at the time when the pinnacles were already formed but still covered with sand. It is possible, that this carbonate layer is still forming at present on exposed surfaces, but not fast as the wind is eroding it as it forms.

The stronger cemented material, which now forms the pinnacles, is in most places a remainder of the primary calcarenite (and its sediment layers, such as calcrete and paleosoil), and in other places secondarily cemented material (cemented fill within pipes/tubes and strongly cemented tube rims). Cemented fill within pipes/tubes differs from the main calcarenite in the lack of visible dune bedding (see area 2 in Fig. 6) and in a greater rhizolith density (Fig. 5), yet strongly cemented tube rims differ in the presence of concentric laminae following the walls of solution pipes (Fig. 3). In some pinnacles both sorts of material occur together (Fig. 6).

\section{SECONDARILY CEMENTED PIPE FILL}

Secondarily cemented material accumulated and was cemented as a fill within vertical tubes/pipes. In places, especially at the bottom of the pinnacle, it is surrounded by outer strongly cemented rims, which makes the fill material much more obvious (Fig. 5). The sediment structure of these rims consists of vertical tubular layers of less porous material, which is a result of the redeposition of carbonates from the inside of the vertical tube to its edge.

In this paper, the term "vertical tube" overlaps with the term "solution pipe", but is used to distinct between 
(1) the small, average solution pipes exposed within and on the sides of many pinnacles (Figs. $3 \& 9$ ) and (2) the larger and less common solution pipes, together with their cemented fills, which now form a complete pinnacle in their own right (Fig. 5).

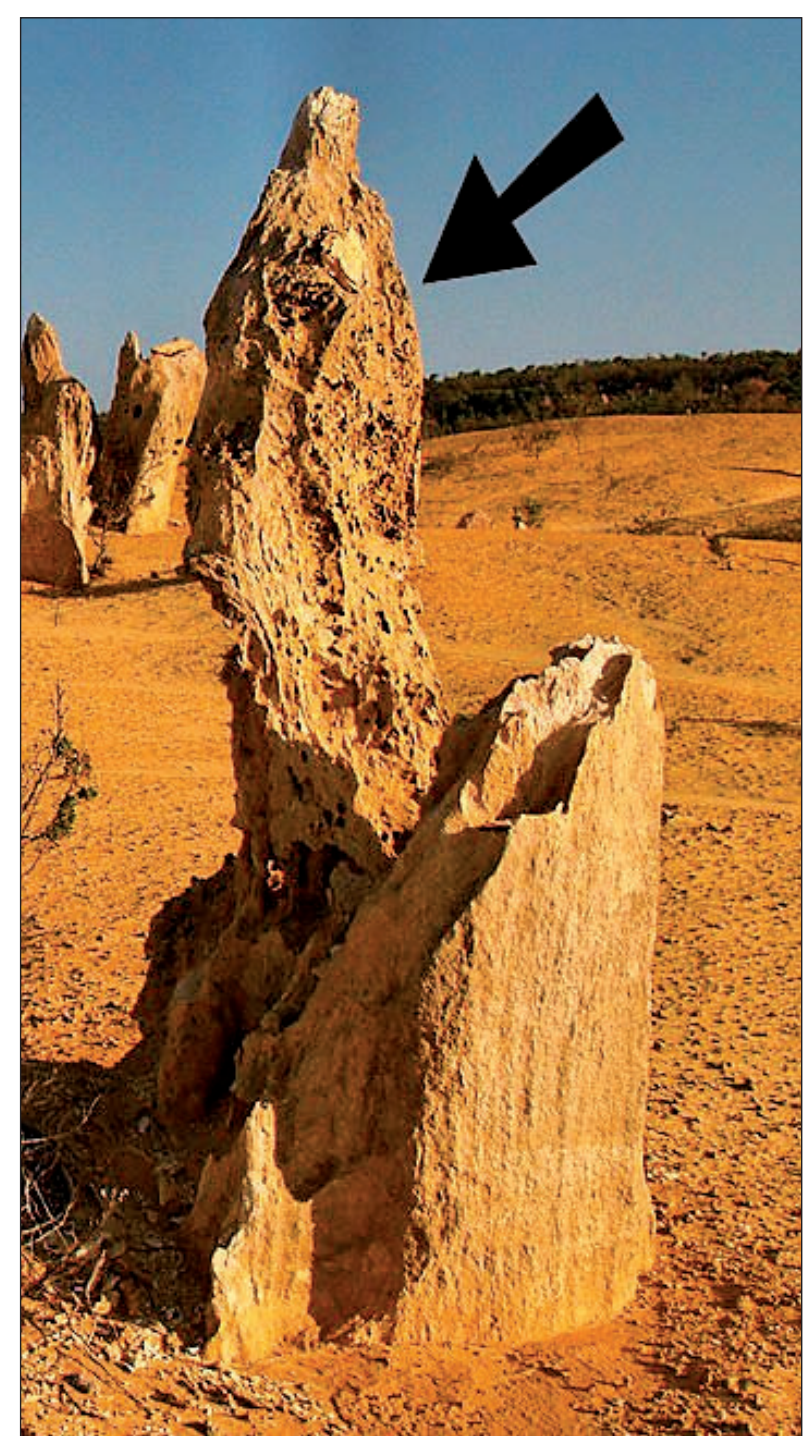

Fig. 5: A pinnacle ( 2.5 metres high), formed of the cemented fill of a vertical tube (pointer). At the bottom, the well cemented rim of the vertical tube is seen (Photo: M. Lipar).

Vertical tubes could have formed around a bigger plant-root (Lundberg \& Taggart 1995), which, because of mechanical pushing and chemical dissolving of the sediment, triggered a focused water flow and therefore the solution of a vertical tube. The same process was suggested by Alonso - Zarza et al. (2008), who interpreted certain vertical tube-like structures with cemented rims on Canary Island as "megarhizoliths", because they ap- pear to be the remains of roots. In addition to plantroots, focused water flow could also be concentrated by the upper parts of the plants (stem flow, see Lundberg \& Taggart 1995), or it could just be focused beneath surface hollows in an exposed calcrete (Lundberg \& Taggart 1995) or through porous patches in a developing calcrete (Grimes 2004, in prep.). Hearty and O'Leary (2008) suggested that the formation of the vertical tubes in The Pinnacles area resulted from burial of trunks of a former generation of trees, which grew on an older dune. A reason for the burial of the forest with sand could, for example, be a climate change. The buried tree trunks rotted and the empty moulds were then filled with material from above.

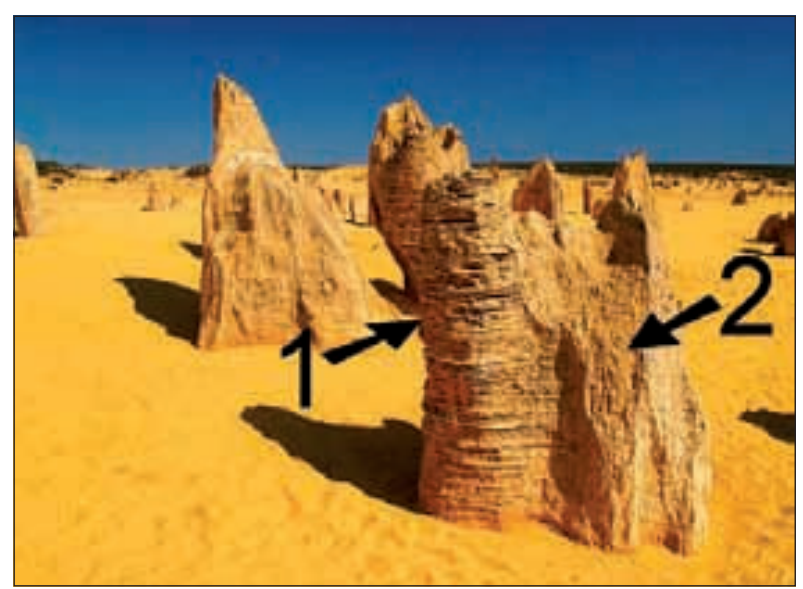

Fig. 6: Combination of two different types of material: as primary bedded calcarenite (1) and secondary cemented material (2) (Photo: M. Lipar).

The hypothesis proposed in this paper is that the formation of a vertical tube was a consequence of root growth, which also produced the rhizoliths that appear as part of some pinnacles. However, a polygenetic view of genesis of vertical tube should also be considered, incorporating one or more of the above-mentioned processes of root influence, stem flow, porous patches in a developing calcrete, surface hollows, and buried tree-trunks.

Once initiated by the root growth, and associated solution, focused water flow expanded and deepened the vertical tube. The space was later filled with sediment (probably soil mostly), and at the same time root growth was concentrated inside, as shown by the rhizoliths. The rims of the vertical tube were cemented strongly as a result of redeposition of carbonates from the inside. Later on the fill in the vertical tube was also cemented by carbonate derived from an overlying dune layer. 
In this fill smaller solution pipes are found, which could, according to Alonso - Zarza et al. (2008), also be interpreted as rhizoliths or megarhizoliths.

Laterite (non-carbon, Fig. 7) pebbles are in some places cemented into the fill and are probably a remainder of a crushed thin laterite crust that formed on a calcarenite, which can be proved by their mineralogy and flatness. The laterite pieces are another indicator, that the fill in which they occur, is not a primary calcarenite, but was washed in as a fill.

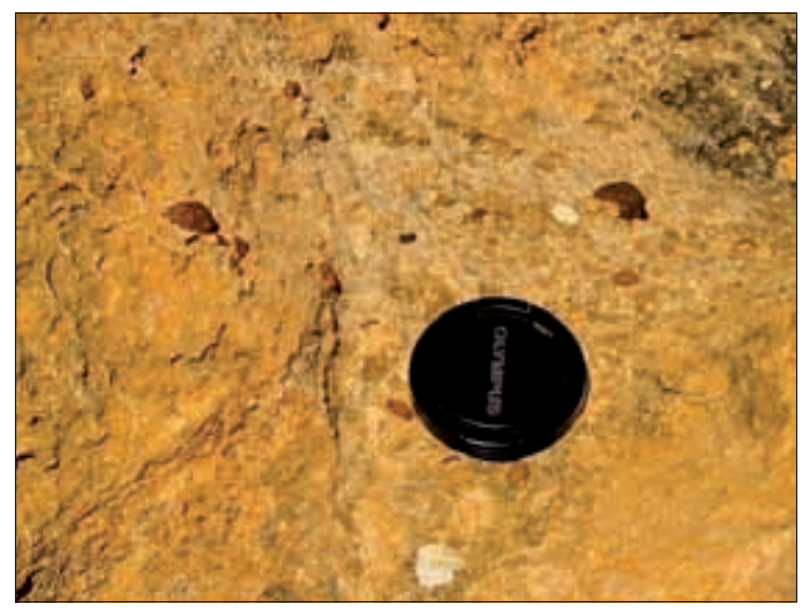

Fig. 7: Laterite pebbles or nodules cemented within a pinnacles' material (cemented fill within pipes/tubes) (photo: Matej Lipar).

\section{A PRIMARY CALCARENITE AND ITS SEDIMENT LAYERS}

There is evidence that many pinnacles are erosional remainders of a primary calcarenite - indicators are the stacking of various layers of material within a pinnacle (for example, bedded dune sand, paleosoil, and calcrete, Fig. 2) and also the connections seen between the bases of adjoining pinnacles (Fig. 4).

Some pinnacles have rounded upper layers, which are usually wider than lower layers. In these the upper layers are a hard calcarenite, probably calcrete. In some other pinnacles that are erosional remainders of a primary calcarenite the upper layers have irregular shapes with shallow hollows at the top, which mostly result from solution pipes.

Softer layers with etched out horizontal or partly inclined sediment layers are most likely dune bedding. Some caution is needed with strictly horizontal bedding as it may indicate secondary cemented fill of a vertical tube (in an hour glass manner).

Another softer layer is formed by paleosoils. Paleosoils can be distinguished from other layers by their different (slightly reddish) colour and by having a greater number of rhizoliths.
In some pinnacles there is a hard calcarenite, calcrete, occurring as the lowermost layer. Although cemented layers (calcrete) at depth can sometimes result from cementation at the watertable, this is unlikely in Nambung National Park. The lower calcrete layers can appear alone or be overlain by a paleosoil, and solution pipes occur within them. Epikarstic features, such as solution pipes and the paleosoils indicate that the lower calcrete layer was once exposed to exogenous processes. Later the surface was buried by a younger dune, which hid the older calcarenite underneath, including the calcrete and soil. The younger sediment has also been cemented and occurs in the uppermost part of a pinnacle.

Pinnacles formed on primary calcarenite materials exist because they have been cemented more than the surrounding sediment. This cementation may have occurred around a small tube (or solution pipe) or simply by focused flow (focused cementation) around a root without the formation of any tube, including solution pipe.

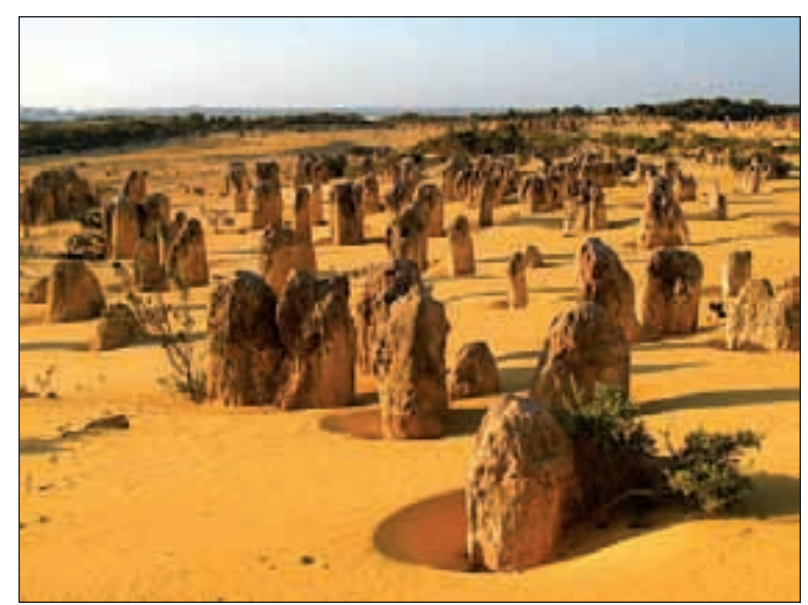

Fig. 8: Cylindrical and round-topped pinnacles $(\sim 2-3$ metres high) in Nambung National Park (Photo: M. Lipar).

\section{DIFFERENT AGES OF PINNACLES MATERIAL}

The structures of the pinnacle layers indicate different ages of the pinnacle materials and even different ages of the pinnacles (regarding only exposed parts) themselves.

In the Nambung area some pinnacles expose a stratigraphic sequence of calcrete at the bottom, paleosoil in the middle and a younger bedded dune sand at the top (Fig. 2). This shows that the pinnacles are built of materials with different ages: the calcrete and the overlying paleosoil, indicate an old landsurface on an earlier dune, that was buried by a younger dune that was later cemented.

In places, erosional lowering of the land surface has exposed lower parts of the pinnacles, displaying the 
older calcarenite beneath the calcrete layer (mentioned above), but has destroyed the younger layers at the tops of the pinnacles.

\section{DIFFICULTY IN INTERPRETING THE PINNACLES}

Interpretation of certain pinnacles can be difficult where the pinnacles are mainly covered by sand and only the upper layer can be inspected. For example, the exposed calcrete part may have cemented rims of solution pipes, or be irregularly shaped because of shallow solution pipes. In this case the visible part of the pinnacle could be explained as a strongly cemented rim of solution pipes or as a coalescence of rims adjoining solution pipes (e.g. Fig. 3 ), but that would, of course, only refer to the exposed part of the pinnacle.

\section{CONCLUSIONS}

The pinnacles are best developed in a dense group in a small area of Nambung National Park in Western Australia called The Pinnacles. They are small towers of calcarenite up to 5 metres tall and up to 2 metres wide with a variety of shapes and have been further modified by corrosion and wind erosion up to the present.

They have formed by erosion (especially corrosion and wind erosion) of the surrounding material to leave the more resistant parts as pinnacles.

Some of the pinnacle material is a primary calcarenite and its component layers, such as bedded dune sand, calcrete and paleosoil. Their stronger resistance is probably a result of stronger focused cementation, which could be partly triggered by roots with chemical and mechanical processes. Rhizoliths exposed in the pinnacle material indicate the presence of plant roots in the past.

Other pinnacle material is secondary cemented pipe/tube fill. A polygenetic origin of these vertical tubes is possible, where the most important genesis of tubes is a solution by a concentrated water flow triggered by root activity.

Some pinnacles contain both sorts of material together.

The genesis of the pinnacles is far more complex than most of the theories presented so far. The most likely model is the polygenetic approach suggested by Grimes (in prep.), which says that no one process can explain all the features we see, and which includes the processes suggested by Lowry (1973) and McNamara (1995). Detailed further research is necessary for the separation of the processes and significant factors (locations, depth of sediment layers, etc.) that resulted in the diversity of pinnacle types.
Regarding the suggestion by Hearty and O'Leary (2008), that the pinnacles were derived from buried trees: firstly that would only apply to the minor subset of pinnacles that were formed of the cemented fill of tubes or by the cementation about a tube, and not the others which lack a central tube and are crossed by undisturbed bedding or other structures. There are several counter-arguments (listed in Grimes 2004, in prep.), in particular, there are localised areas with very dense spacing (closer than 1 metre) and the width (up to 1 metre) of pinnacles that seems to be too close a spacing for the size of the trees that the pinnacles width suggests. Nevertheless, buried trees could be involved in some places, where there are pinnacles of secondary cemented pipe/ tube fill and are not too densely spaced and have no different layers of sedimentation crossing them.

We need further research to determine, firstly if the pinnacles all formed at the same time or at several times (related to a series of old land surfaces), and secondly, if the latter case is true, whether the same processes operated to form the older and younger pinnacles.

Last but not least: it is necessary to find out what factors have resulted in the high density and complexity of the pinnacles in The Pinnacles desert area. Pinnacles do occur elsewhere (McNamara 1995) but not in such large numbers. Root activity, presence of the solution pipes (vertical tubes), corrosion and wind erosion are all present in the surrounding areas, but without the pinnacles. 


\section{ACKNOWLEDGEMENTS}

I wish to thank Nambung National Park staff, especially Paul Udinga, who helped me collected the rock samples according to Nambung National Park rules.
I also wish to thank Ken G. Grimes for discussions and critical comments on the text and to Meta Dobnikar for helping with X-ray analysis of the rock samples.

\section{REFERENCES}

Alonso - Zarza, A. M., Genise, J., Cabrera, M. C., Mangas, J., Martín - Pérez, A., Valdeolmillos, A. \& M. Dorado - Valiño, 2008: Megarhizoliths in Pleistocene aeolian deposits from Gran Canaria (Spain): Ichnological and palaeoenvironmental significance.- Palaeogeography, Palaeoclimatology, Palaeoecology, 265, 1-2, 39-51.

Annual record of daily rainfall at CALM Cervantes 19902007.- Nambung National Park (internal source), Cervantes.

Climate statistics for Australian locations, 2008: Australian Government, Bureau of Metorology.- [Online] Available from http://www.bom.gov.au (Accessed $15^{\text {th }}$ June 2008).

Csaky, D., 2003: Review of karst hazards in the Wanneroo area, Perth, Western Australia.- Minerals and Geohazards Division Perth Cities Project, Geoscience Australia, Canberra.

Dobnikar, M., 2008: Unpublished report of X-ray analysis of the rock samples.- Department of Geology, Faculty of Natural Sciences and Engineering, University of Ljubljana.

Grimes, K. G., 2002: Syngenetic and eogenetic karst: an Australian viewpoint.- In: Gabrovšek, F. (ed.), »Evolution of karst: from prekarst to cessation «, Založba ZRC, Ljubljana, 407-414.

Grimes, K. G., 2004: Solution Pipes or Petrified Forests? Drifting sands and drifting opinions!- The Victorian Naturalist, 121, 1, 14-22.

Grimes, K. G., 2006: Syngenetic karst in Australia: a review.- Helictite, 39, 2, 27-38.

Grimes, K. G., (in prep.): Solution pipes and pinnacles in syngenetic karst.- In: Dreybrodt, W., Gines, A., Knez, M. \& T., Slabe (eds.), »Karst Rock Features, Karren Sculpturing«, Založba ZRC, Ljubljana.
Hearty, P. J. \& M. J. O’Leary, 2008: Carbonate aeolianites, quartz sands, and Quaternary sea-level cycles, Western Australia : A chronostratigraphic approach.Quaternary Geochronology, 3, 26-55.

Jennings, J. N., 1968: Syngenetic karst in Australia.- In: Williams, P. W. \& J. N. Jennings (eds.), Contributions to the Study of Karst, Department of Geography Publication no. G/5, Australian National University, 41-110.

Lowry, D. C., 1973: Origin Of The Pinnacles, Nambung, WA.- ASF Newsletter, 62, 7-8.

Lowry, D. C., Low, G. H., Playlord, P. E. \& R. Dedman 1973: Dongara - Hill River Geological Map.- Geological Survey of Western Australia, Perth.

Lundberg, J. \& B. E. Taggart, 1995: Dissolution pipes in northern Puerto Rico: An exhumed paleokarst.Carbonates and Evaporites, 10, 2, 171 - 183.

McNamara, K., 1995: Pinnacles.- Western Australian Museum, Perth.

Mory, A. J., 1995: Geology of the Wedge Island 1:100.000 Sheet.- Geological Survey of Western Australia, p. 19 and geological map, Perth.

Nambung National Park Management Plan 1998-2008, 1998.- Department of Conservation and Land Management, p. 64, Perth.

Sando, W. J., 1987: Madison Limestone (Mississippian) paleokarst: a geological synthesis.- In: James, N. P. \& P. W., Choquette (eds), »Paleokarst«, SpringerVerlag, NY, 256-277. 